\title{
NON-RECOGNITION: A RECONSIDERATION
}

Whenever a government is created, each member of the family of nations must either grant or withhold recognition. The United States with few exceptions has granted recognition to every new government, regardless of its origin or principles of government, provided only that it have "the control of the administrative machinery of the state; the general acquiescence of its people; and the ability and willingness ... to discharge international and conventional obligations." In 1932, however, Secretary of State Stimson announced that the United States would not recognize any government created by conquest. ${ }^{2}$

\footnotetext{
${ }^{1}$ Memorandum of Assistant Secretary of State (Adee), MS. Dep't State file 893.00/ 1669 ; U.S. Foreign Rel. 100-103 (1913); quoted in 1 Hackworth, Digest of International Law 176 (1940). See also 1 Hyde, International Law 161-65 (1945); Goebel, The Recognition Policy of the United States 219-21 (1915).
}

The so-called "de facto" or "stability" doctrine of recognition was initiated by Jefferson in 1793 in recognizing the new French republican government. His announcement established an objective criterion of recognition requiring only control of the government and the acquiescence of the people. The prerequisite of ability and willingness to discharge international and conventional obligations was first stated by President Hayes in 1877 with reference to the delayed recognition of the Diaz government of Mexico. 1 Moore, Digest of International Law 148 (1906). The latter requirement was probably added to the de facto test in order to protect American investments in the countries concerned, for history shows that interest in this condition is in direct ratio to the amount of American investments in the country. Neumann, Recognition of Governments in the Americas, c. I-II (1947).

The exceptions to the general policy before 1932 referred to are non-recognition policies directed entirely toward Latin-American nations. The Central American Treaties of 1907 and 1923 (which the United States endorsed, although it was not a signatory) and the Wilsonian Doctrine announced in 1913 committed the United States to a policy of non-recognition of those Latin-American governments brought about by revolutionary or unconstitutional means. Although Wilson's determination to use recognition as a means of encouraging constitutional development and democratic habits in Latin-American countries was novel, the requirement of a proper expression of popular consent was based on a long line of precedent and went back to Jefferson's insistence on "the will of the nation substantially declared" as a condition of recognition. 3 Jefferson's Works 489 (4th ed., 1939), quoted in 1 Moore, Digest of International Law 120 (1906).

The Hoover administration, however, abandoned the test of "constitutionality" as a prerequisite to the recognition of governments, except in Central America. Secretary of State Stimson said on February 6, 1931: "The present administration has refused to follow the policy of Mr. Wilson and has followed consistently the former practice of this Government since the days of Jefferson." Quoted in 1 Hackworth, Digest of International Law 186 (1940).

There are several Pan-American treaties and resolutions dating from about 1890, some of which the United States has signed, which expressly require non-recognition of all those conquests made in Latin America. See McMahon, Conquest and Modern International Law (1940); Hyde, Conquest Today, 30 Am. J. Int. L. 471 (1936).

${ }^{2}$ That is to say, the United States will recognize neither a new government created by aggression, such as a puppet government established by the conquering government, nor the extension of authority by a pre-existing government over territory acquired by conquest.

The word conquest has perhaps two definitions. It can refer to any seizure of territory by force or only to those seizures in which force is used illegally, often called aggression. The Stimson note and the Pact of Paris condemned the latter, but they did not condemn, for example, a conquest made in self-defense. Such a conquest is perhaps 
Since 1932, the United States has formally refused recognition to conquests. ${ }^{3}$ Yet, it has engaged in conduct with respect to governments created by conquest which seems, on the surface at least, to be inconsistent with non-recognition. For example:

"just." In the present discussion the word conquest is used to refer to the illegal use of force and is synonymous with the word aggression.

The non-recognition announcement was contained in a letter to Japan and China which referred to the Japanese conquest of Manchuria. In September of 1931 the Japanese army invaded Manchuria, successfully occupying the entire region and establishing a puppet government. The military operations were defended by Japan as necessary measures of self-defense [see Japan's note of February 23, 1932, to the League Council, 13 L. Nations Off. J. 384 (1932) ] but were condemned by the rest of the world as unmitigated steps of aggression. The League of Nations was then in session and attempted to negotiate a peaceful settlement between China and Japan.

With the continued aggression of Japan in Manchuria, however, it became apparent that little hope existed for a solution of the problem by conciliation. Hence, on January 7, 1932, Secretary Stimson sent his now famous note: "With the recent military operations about Chinchow, the last remaining administrative authority of the Government of the Chinese Republic in South Manchuria, as it existed prior to September 18th, 1931, has been destroyed. The American Government continues confident that the work of the Neutral Commission recently authorized by the Council of the League of Nations will facilitate an ultimate solution of the difficulties now existing between China and Japan. But, in view of the present situation and of its own rights and obligations therein, the American Government deems it to be its duty to notify both the Imperial Japanese Government and the Government of the Chinese Republic that it cannot admit the legality of any situation de facto, nor does it intend to recognize any treaty or agreement entered into between those Governments, or agents thereof, which may impair treaty rights of the United States or its citizens in China, including those which relate to the sovereignty, the independence, or the territorial and administrative integrity of the Republic of China, or the international policy relative to China, commonly known as the Open-door policy; and that it does not intend to recognize any situation, treaty, or agreement which may be brought about by means contrary to the covenants and obligations of the Pact of Paris of August 27, 1928, to which treaty both China and Japan, as well as the United States, are parties." Dep't State Press Releases, at 41-42 (Jan. 9, 1932).

Although the Stimson note referred specifically to the Manchurian incident, it was a statement of the general policy of the United States extending to "any situation, treaty or agreement" brought about by means contrary to the Pact of Paris, i.e., "non-pacific" means.

For details on the Manchurian conquest see the Lytton Report, League of Nations Document C.663.M.320-1932 VI, and Stimson, The Far-Eastern Crisis (1936). For comments on the Stimson note see Williams, The New Doctrine of Recognition, 18 Transactions of the Grotius Society 109 (1932); Wright, The Stimson Note of January 7, 1932, 26 Am. J. Int. L. 342 (1932) ; Hill, Recent Policies of Non-recognition, International Conciliation, no. 293 (Oct. 1933) ; McNair, The Stimson Doctrine of Non-recognition, 14 Brit. Y. B. Int. L. 65 (1933) ; Middlebush, Non-recognition as a Sanction in International Law, 27 Proc. Am. Soc. Int. L. 40 (1933); Sharp, Duties of Non-recognition in Practice, 1775-1934, 5 Geneva Special Studies no. 4 (1934); Stimson, The Far-Eastern Crisis (1936) ; Briggs, Non-recognition of Title by Conquest and Limitations on the Doctrine, 34 Proc. Am. Soc. Int. L. 72 (1940) ; Langer, The Seizure of Territory (1947); Lauterpacht, Recognition in International Law (1947) ; Chen, The International Law of Recognition (1951). For a general discussion of the legal effects of non-recognition in the Far East see Legal Problems in the Far Eastern Conflict (Wright ed., 1941).

The policy enunciated in the letter of January 7 has come to be known generally as the 
(1) The United States did not recognize the German conquest of Austria in 1938, yet in 1939 the United States and Germany agreed to extend their extradition treaty to the territory which had been Austria. ${ }^{4}$

(2) The United States did not recognize the Soviet annexation of Latvia in 1940 or the puppet government established. In 1950 an unarmed American navy patrol plane was shot down by Soviet fighters either over the territory of Latvia or over the Baltic off the coast of Latvia. The Soviet government sent a note of protest claiming that the plane had flown over Soviet territory and had fired upon Russian aircraft when instructed to land. The United States asserted in reply that all planes had been instructed not to fly over foreign territory, that the plane was unarmed and that the Soviet action constituted a "violation of International Law and of the most elementary rules of peaceful conduct between nations." But the United States failed to advance the defense it could have: that it did not recognize Soviet authority in Latvia. ${ }^{6}$

(3) The United States did not recognize the Chinese Communist government, yet it consented to meet with the Chinese Communists at the Geneva Convention in 1954. Is it significant that the United States announced that such action did not imply a recognition of the Chinese Communist government? ${ }^{7}$

Whether American actions in the above instances belie a declaration of nonrecognition is open to question. To answer that question it is necessary to examine the nature and significance of recognition and non-recognition.

International recognition is the acknowledgment or avowal by an international legal person ${ }^{8}$ that certain legal consequences flow from the existence

Stimson Doctrine. President Hoover, however, apparently wanted it to be known as the Hoover Doctrine and claimed it as his own. Current, Secretary Stimson: A Study in Statecraft (1954), points out that Hoover was probably in large part responsible for the origination and application of the doctrine; although one gets a somewhat different impression from Stimson's book The Far-Eastern Crisis (1936).

The policy is also sometimes called the Hoover-Stimson Doctrine.

${ }^{3}$ Consult Langer, Seizure of Territory, Part III (1947), for a complete survey of diplomatic practice from 1934 until 1946.

-Ibid., at 167.

\$N.Y. Times \& 1, p. 3, col. 2 (April 19, 1950).

- For an account of the Baltic plane incident, see N.Y. Times $\$ 1$, p. 1, col. 8 (April 12, 1950). See also ibid., at p. 3, col. 3, 4 (Soviet note of April 11); N.Y. Times $\$ 1$, p. 3 , col. 2 (April 19, 1950) (U.S. note of April 19); N.Y. Times $\$ 1$, p. 2, col. 2, 3 (April 22, 1950) (Soviet note of April 21) ; N.Y. Times \$ 1, p. 3, col. 4 (May 6, 1950) (U.S. note of May 5).

${ }^{7}$ Address of Secretary of State Dulles on February 24, 1954. Dep't State-For the Press, No. 93.

${ }^{8}$ That is, a government or international organization such as the League of Nations or the United Nations. 
of some object or from the occurrence of some event. Recognition may be extended to international transactions such as treaties and annexations of territory as well as to governments. ${ }^{9}$ Recognition between governments is said to be of two kinds: de jure and de facto. Although the terms have been used by different writers to mean different things, there seems to be a developing consensus that de facto recognition has the connotation of the qualified and provisional; that a nation in granting de facto recognition makes it clear from the beginning that the recognition may subsequently be withdrawn..$^{10} \mathrm{De}$ jure recognition, on the other hand, is absolute, unqualified and, some say, irrevocable. ${ }^{11}$ The judicial effects of a de facto and de jure recognition, however, are identical. ${ }^{12}$

Recognition is in essence a matter of intention and may be manifested expressly - for example, by a public statement or formal note-or implicitlyfor example, by request for a consul's exequatur or the conclusion of a treaty with the government in question. ${ }^{13}$ The act constituting recognition must, however, give a clear indication of a willingness to accept the government's authority to represent the state it purports to govern. ${ }^{14}$

The purpose of recognition is an issue long disputed among international jurists. Those authors who maintain the declaratory theory consider recognition an act which officially acknowledges the existence of a state and which indicates a readiness on the part of the recognizing state to enter into formal relations with it. The advocates of the constitutive theory, on the other hand, believe that recognition is the declaration of the existence of the requisite conditions of statehood, a declaration which creates in the recognized state the

${ }^{\circ}$ It is often stated that those objects or events which are recognized are of two types, standard objects including governments and states and secondary objects including treaties, acquisitions of territory, etc.

${ }^{10}$ Briggs, De Facto and De Jure Recognition: Arantzazi Mendi, 33 Am. J. Int. L. 689, 690 (1939) ; Langer, Seizure of Territory 112 (194h); Lauterpacht, Recognition in International Law, c. 19 (1947); Chen, The International Law of Recognition, c. 18 (1951).

I1 Despite what some writers say about the supposed irrevocability of recognition, there are many instances in which de jure recognition has been withdrawn. For example, in a case tried before the Palestine Supreme Court on December 11, 1940 (Azazh Kebbeda Tesema v. Italian Government, Ann. Dig. 1938-40, No. 36, 93), the High Commissioner of Palestine informed the court by letter of November 30, 1940, as follows: "I have been acquainted by the Secretary of State for Colonies that the de jure recognition by His Majesty's Government of the Italian conquest of Ethiopia has been withdrawn."

${ }^{12}$ Lauterpacht, Recognition in International Law 345-46 (1947).

${ }^{23}$ Recognition may be implied by the conclusion of a treaty between two nations only if they simultaneously negotiate and agree upon the terms of the instrument. Recognition may not be implied if the unrecognized government later accedes to a multilateral treaty to which the non-recognizing government is a signatory.

"A court should proceed cautiously in implying recognition. Unless the intention to recognize is clearly implied in certain conduct, the court should consult the State Department concerning the status of the government in question since recognition is an executive, not a judicial, function. See note 56 infra at (a). 
normal rights and duties which international law attaches to states. Lauterpacht, an exponent of the constitutive theory, asserts that there is a duty to recognize those governments which have satisfied the requisites of governmental capacity. It must be admitted, however, that, regardless of any duty, a state has the power to grant or deny recognition as it chooses. A government may grant recognition to any government which is able to establish itself in fact, or it may withhold recognition from certain de facto governments.

The withholding of acknowledgment or avowal by an international legal person that certain legal consequences flow from the existence of some object or the occurrence of some event is non-recognition. It is the denial of the legal status of that from which it is withheld. ${ }^{15}$ Non-recognition may be applied to those governments which have not satisfied certain requirements or which merely do not meet with the approval of the recognizing state. The denial of recognition, therefore, may be an instrument in international relations to further any desired goal.

There were many instances before 1932 in which one nation had withheld recognition from another. ${ }^{16}$ Yet there was apparently no attempt to analyze non-recognition or to determine its proper application. The Stimson note of January 7, 1932, and the League of Nations' resolution of March $11^{17}$ which adopted a policy of non-recognition of conquests stimulated a great deal of discussion on the nature and purpose and application of non-recognition. The

\footnotetext{
${ }^{15}$ Non-recognition, therefore, is inconsistent with both de jure and de facto recognition. Lauterpacht, however, maintains that non-recognition applies only to de jure recognition and that the non-recognizing government implies de facto recognition when it engages in conduct inconsistent with non-recognition. Lauterpacht, Recognition in International Law 431-35 (1947).
}

${ }^{10}$ I Moore, International Law Digest, c. III (1906); Sharp, Duties of Non-recognition in Practice, 1775-1934, 5 Geneva Special Studies no. 4 (1934) ; 1 Hackworth, Digest of International Law, c. III (1940).

\footnotetext{
${ }^{27}$ Following the lead of Secretary Stimson, the League of Nations adopted the following resolution on March 11, 1932: "The assembly [c] onsidering that the provisions of the Covenant are entirely applicable to the present dispute... [r]ecalling the fact that twelve Members of the Council ... declared 'that no infringement of the territorial integrity and no change in the political independence of any Member of the League brought about in disregard of Article 10 of the Covenant ought to be recognized as valid and effectual by Members of the League of Nations'... [p]roclaims the binding nature of the principles and provisions referred to above and declares that it is incumbent upon the Members of the League of Nations not to recognize any situation, treaty or agreement which may be brought about by means contrary to the covenant of the League of Nations or to the Pact of Paris." L. Nations Off. J. 87 (Sp. Supp. 101, 1932).

Although the precise legal effect of the resolution has been disputed, the League members did express their determination to refuse to grant recognition to conquests. It is not necessary to pursue the controversy as to whether the resolution of the Assembly, in addition to being declaratory of existing obligations, was in itself a source of obligation. For further discussion see Hill, Recent Policies of Non-recognition, International Conciliation no. 293 (Oct. 1933); Williams, Some Thoughts on the Doctrine of Recognition in International Law, 47 Farv. L. Rev. 776 (1934); 16 Brit. Y. B. Int. L. (1935); Langer, Seizure of Territory 96 (1947).
} 
interest was evoked for at least three reasons. The resolution of the League was the first instance in which a great many nations agreed to act together in refusing recognition. ${ }^{18}$ Secondly, the non-recognition policy was directed against conquest. And, finally, the advocates of non-recognition predicted that the policy would have substantial results. They claimed that non-recognition was a powerful sanction which would prevent aggression and restore rights to injured states without the use of force. ${ }^{19}$ Its effectiveness as a sanction resulted, it was said, from the united manifestation of the public opinion, conscience and moral sentiment of the world. ${ }^{20}$ "Moral disapproval, when it becomes the

${ }^{18}$ There have been situations in which a small number of nations have agreed to withhold recognition in certain instances. Sharp, Duties of Non-recognition in Practice, 17751934, 5 Geneva Special Studies no. 4, 4-9 (1934). But the resolution was the first instance in which practically all the nations of the world had agreed on such a course of action.

${ }^{10}$ On May 4, 1932, Mr. Castle, acting Secretary of State, observed that "in the mechanism of international relations a stern deterrent to the use of force would be to make valueless the results of war. . . . The spoils of war become Dead Sea fruits. . . . [Nonrecognition] is a powerful sanction without the use of force ... [and involves] no danger of war arising out of boycotts." Dep't State Press Releases, at 418-19 (May 7, 1932). On May 6 he said, "no . . . nation in the future will be permitted to enjoy the fruits of its dishonest attack on the peace structure of society," and "[t]hrough this action the President has 'put teeth in the Pact' and has done it in a way which avoids the use of force." Ibid., at 446. Secretary Stimson on Feb. 23, 1932, considered that a general adoption of the policy of the United States "will eventually lead to the restoration to China of rights and titles of which she may have been deprived." Ibid., at 205 (Feb. 27, 1932).

${ }^{20}$ Secretary Stimson stated on Feb. 23, 1932, that the object of the Pact of Paris and the Nine Power Treaty was to align "the conscience and public opinion of the world in favor of a system of orderly development by the law of nations, including the settlement of all controversies by methods of justice and peace instead of by arbitrary force." Dep't State Press Releases, at 204 (Feb. 27, 1932). Mr. Castle stated, "I have great confidence in the validity of the decisions which may be reached by the conscience of mankind, and I think there will be little chance in the future of any serious division in opinion as to the guilt which must be placed on the nation because it ignores its obligations under the Kellogg Pact" [ibid., at 446 (May 7, 1932)], and "I believe that the consciences of the different nations generally run along the same lines. ..." Ibid., at 419 (May 7, 1932). He further stated that "[a]s the President says, it is the strongest moral sanction the world has ever known." Ibid., at 446 (May 7, 1932). Mr. Hornbeck, Chief of the Division of Far Eastern Affairs, Dep't State, stated on April 29, 1932, that the Pact of Paris "must rely, for efficacy, upon the sanction of public opinion." Ibid., at 396 (April 30, 1932). Secretary Stimson stated on August 8, 1932, that the refusal of the United States "to recognize the fruits of aggression might be of comparatively little moment to an aggressor. But when the entire group of civilized nations took their stand beside the position of the American Government, the situation was revealed in its true sense." At the same time he said that one must assume that behind the Pact of Paris "rests the combined weight of the opinion of the entire world united by a deliberate covenant which gives to each nation the right to express its moral judgment," and that the United States on Jan. 7, 1932, was "appealing to a new common sentiment." Pub. of Dep't State No. 357. President Hoover stated on August 12, 1932, that acceptance of his doctrine by "all nations of the world" is "public opinion made tangible and effective." N.Y. Times $\$ 1$, p. 4, col. 7 (Aug. 12, 1932). Secretary Stimson stated on October 1,' 1932, that the success of the American policy "can be measured by the unanimous alignment of all the neutral governments and substantially all the public opinion of the world behind the so-called 'nonrecognition' policy" of the United States. Dep't State Press Releases, at 269 (Oct. 22, 
disapproval of the whole world, takes on a significance hitherto unknown in international law."21 They claimed, finally, that non-recognition would alter certain principles of international law..$^{22}$

The League of Nations' Assembly established an Advisory Committee on February 24, 1933, to recommend an appropriate pattern of administrative conduct for the non-recognizing governments. ${ }^{23}$ After investigations, the committee issued a report on June $14,1933 .{ }^{24} \mathrm{It}$ is significant as the first attempt to translate non-recognition into concrete terms. The committee advised that the Manchukuo government should not be allowed to accede to any international convention including the Universal Postal Union. It recommended that non-recognizing governments should not recognize any document issued by the Manchukuo government purporting to be a passport, nor should they admit official quotations of Manchukuo currency. But the committee did suggest that without implication of recognition a citizen of Manchukuo could be granted a passport by a non-recognizing government; transactions in Manchukuo currency could be allowed, since domestic currency is utilized in the same way as any other object of value obtainable in the international market; the nationals of a non-recognizing state could enter into contractual relations with

1932). President Hoover stated on October 7, 1932, that the United States had "definitely secured that the public opinion of the world will be mobilized and concentrated against those who violate" the Pact of Paris. Ibid., at 210 (Oct. 8, 1932).

${ }^{11}$ Address by Secretary Stimson, Aug. 8, 1932. Pub. of Dep't of State No. 357.

2 Secretary Stimson, in a letter to Senator Borah, Feb. 23, 1932, said: "If a similar decision should be reached and a similar position taken by the other governments of the world, a caveat will be placed upon such action which, we believe, will effectively bar the legality hereafter of any title or right sought to be obtained by pressure or treaty violation, and which, as has been shown by history in the past, will eventually lead to the restoration to China of rights and titles of which she may have been deprived." Dep't State Press Releases, at 205 (Feb. 27, 1932).

${ }^{23}$ On January 14, 1932, the League of Nations appointed the Commission of Enquiry (known as the Lytton Commission) to study and report on the situation in Manchuria (note 2 supra). The commission reported on October 1 that the Manchukuo government was a puppet state created by Japanese aggression and recommended that it not be recognized, pursuant to the resolution of March 11 (note 17 supra). League of Nations Document C.663.M.320-1932 VII.

On February 24, 1933, the League adopted the Lytton report and appointed the Advisory Committee: "[W]hereas . . . the Members of the League 'intend to abstain from taking any isolated action with regard to the situation in Manchuria and to continue to concert their action among themselves as well as with the interested States not Members of the League' and, 'in order to facilitate as far as possible the establishment in the Far East of a situation in conformity with the recommendations of the present report ...? ... The Assembly decides to appoint an Advisory Committee to follow the situation ... to aid the Members of the League in concerting their action and their attitude among themselves and with the non-member States. . . ." L. Nations Off. J. 24 (Sp. Supp. 112, 1933).

${ }^{26}$ Report found in L. Nations Off. J. 10-13 (Sp. Supp. 113, 1933). The recommendations met with the approval of practically all of the states approached. $15 \mathrm{~L}$. Nations Off. J. 17 (1934). 
anyone in Manchukuo, and even accept concessions or appointments from the authorities; and that non-recognizing governments could grant applications for the export of opium to Manchukuo provided the applicant produced an import certificate containing satisfactory indications that the opium would not be used for a purpose contrary to the Geneva Opium Convention of 1925. The committee even conceded that governments could maintain and replace consuls in Manchukuo, although these representatives were to be instructed not to act in such a way as to imply recognition.

The committee report has been criticized by recent publications as inadequate and compromising, ${ }^{25}$ yet its approach to the problem is instructive. The report shows that the committee and the League members thought of nonrecognition as a sanction. When it is believed that the expression of world disapproval manifested through non-recognition will have a deterrent effect on the actions of a government, it appears necessary rigidly to adhere to every traditional ramification of that doctrine. ${ }^{26}$ The committee, therefore, outlined conduct appropriate to nations invoking non-recognition, forbidding them to engage in acts considered to imply recognition.

Furthermore, during the period immediately following the Stimson note and the League resolution, many writers summarized the committee report with seeming approval of the recommended conduct. 27 They also seemed to believe that one of the chief virtues of non-recognition was its force as a sanction. ${ }^{28}$

\section{II}

The United States and the members of the League withheld recognition from the Manchukuo government for two years. During that time the territory

${ }^{25}$ "II]t would appear that the Advisory Committee was reluctant to recommend measures which might have impaired the commercial interests of the nationals of the nonrecognizing States, and that it resorted therefore to expedients and half-way solutions. ..." Langer, Seizure of Territory 72 (1947).

${ }^{23}$ In the report of February 24, the nations pledged themselves "not to recognize this regime [Manchukuo] either de jure or de facto." L. Nations Off. J. 76 (Sp. Supp. 112, 1933). And they appointed the Advisory Committee "to aid the Members of the League in concerting their action and their attitude among themselves and with the non-member states." Ibid., at 24.

${ }^{27}$ Wright, the Stimson Note of January 7, 1932, 26 Am. J. Int. L. 342 (1932); Hill, Recent Policies of Non-recognition, International Conciliation no. 293 (Oct. 1933); Middlebush, Non-recognition as a Sanction in International Law, 27 Proc. Am. Soc. Int. L. 40 (1933); Sharp, Duties of Non-recognition in Practice, 1775-1934, 5 Geneva Special Studies no. 4 (1934).

${ }^{23}$ Hill said: "Most of the policies of non-recognition constitute a kind of sanction for international law or foreign policy." Hill, Recent Policies of Non-recognition, International Conciliation no. 293, at 9 (Oct. 1933).

This is not to say that everyone was optimistic about the effect of non-recognition as a sanction. Middlebush and Fill raised some serious doubts about its success. 
was not returned to China, nor did Japanese aggression cease. ${ }^{20}$ The unity of the League members began to disintegrate in 1934, and in succeeding years a number of them granted recognition to the Manchukuo government. ${ }^{30}$ In the only instance of unified action by a large number of the world's nations, nonrecognition had proved a failure as a sanction.

It may be argued that the failure of non-recognition to stop the Manchurian conquest does not prove non-recognition's ineffectiveness as a sanction. In the first place the conquest began in September of 1931, and the League did not adopt its resolution of non-recognition until March of the following year. There was a further delay in waiting for the Advisory Committee report to spell out the concrete application of non-recognition. There can be no question that these delays made League action less effective. Finally, the recommendations when they did appear were compromising. ${ }^{31}$

The report, however, seems essentially sound in attempting to prohibit only that conduct which appears inconsistent with non-recognition. Recognition and non-recognition extend only to governments and not to the people of a state. A non-recognizing government may not acknowledge that any legal significance flows from the acts of the non-recognized government, but it and its nationals are not bound to abstain from dealing with the nationals of the non-recognized country. It is true that the government and nationals of the non-recognized state are placed under some restrictions: The non-recognized government is denied access to the courts of the state withholding recognition; ${ }^{32}$ the ordinary immunities of its public property, its diplomatic representatives and of the government itself appear to be non-existent. ${ }^{33}$ But since

\$ While Japan took no more than Manchuria for the moment, it did not discard its imperialistic attitude. The militaristic elements in the Japanese government consolidated their control and waged an undeclared war with the Chinese Republic from 1937 until 1941, when the Japanese attack upon the American installations at Pearl Harbor on December 7, 1941, caused official declarations of war by the United States, Great Britain and China. There is no indication that non-recognition of the Manchurian conquest even delayed the aggression of the Japanese.

${ }^{30} \mathrm{El}$ Salvador first granted recognition to the Manchurian puppet state in March 1934. Subsequently, the following states recognized Manchukuo: Italy in November 1937; Spain in December 1937; Germany in January 1938; Poland in October 1938; Hungary in January 1939; Rumania in December 1939; and Finland in July 1941. The other members of the League withheld recognition, including Great Britain in spite of her divergent attitude in other cases of aggression.

sI The report resorted to expedient and half-way solutions. For example, it barred official quotations of the Manchukuo currency but did not prohibit transactions in it.

${ }^{32}$ Borchard, The Unrecognized Government in American Courts, 26 Am. J. Int. L. 261,265 (1932). For the effect of non-recognition on judicial remedies consult also Houghton, Recognition in International Law, 62 Am. L. Rev. 228 (1928); Houghton, The Position of Unrecognized Governments before the Courts of Foreign States, 4 Ind. L. J. 519 (1929); Dickinson, Recognition Cases 1925-1930, 25 Am. J. Int. I. 214 (1931); Comment, 19 Univ. Chi. L. Rev. 73 (1951).

${ }^{23}$ Dickinson, The Unrecognized Government or State in English and American Law, 22 Mich. L. Rev. 118, 122, 124 et seq. (1923). 
not all economic relationships are barred, non-recognition falls short of economic boycott. Its only purpose is to give expression to the public opinion of the world, and the committee recommendations were sufficient to do that.

It is in regard to the notion that public opinion through non-recognition is an effective sanction that the Manchurian episode becomes significant. It shows clearly that, although non-recognition is not entirely without its effect, ${ }^{34}$ many factors weaken its force. The officials and nationals of a state may consider foreign criticism unjust, prejudiced, hypocritical or based on misunderstanding of the facts. Further, a state may be willing to risk moral censure and even war if the desired object seems sufficiently valuable. Finally, the condemned state may be governed by experts in molding domestic opinion. ${ }^{35}$

Following the Manchurian incident, non-recognition was never asserted again on a universal scale. The Chaco boundary dispute between Bolivia and Paraguay in 1932 occasioned a concerted resolution by several Pan-American nations that they would refuse to recognize any boundary change resulting from the war. ${ }^{36}$ The resolution had no effect on the disputants. In subsequent

${ }^{3 s}$ That non-recognition had some effect is shown by $R$. H. Sharp who spent the summer of 1933 in Manchuria, China and Japan: "The attitude of the authorities of 'Manchukuo' with regard to the general policy of non-recognition applied to them has been one of studied indifference, belied by the keen desire of those officials to have general world approval for their standing. In a disclaimer given out by the 'Manchukuo Foreign Office' in Tokyo on May 3, 1933, it was declared that: [']The question of recognition or non-recognition has practically no bearing upon the work of Manchukuo's constructive enterprises. Accordingly, this Government has no necessity at present to seek perforce recognition from other nations nor does it wish to indulge in such childish play as to boycott or retaliate against those countries which are withholding their recognition.[']

"This policy, often restated, was pursued on the advice of foreign advisers in the employ of the Manchurian administration and associated with Japanese enterprises. The fact that it was a sham was disclosed by the jubilation manifested in Manchuria and in Japan when Salvador extended formal recognition." Sharp, Duties of Non-recognition in Practice, 1775-1934, 5 Geneva Special Studies no. 4, 14 (1934).

${ }^{35}$ The Manchurian incident also reminded the world that it is not always easy to ascertain what constitutes a conquest or who is the aggressor. Conquests may occur in various and subtle ways: invasions under the guise of self-defense, treaties by coercion and interventions in revolution, for example. Japan claimed that it invaded Manchuria in defense of its nationals and public property. There were some grounds for such a claim. See note 2 supra and the references cited therein.

${ }^{38}$ About the time of the Manchurian incident, the Chaco boundary dispute between Bolivia and Paraguay was raging. During July of 1932 clashes occurred between the armed forces of Bolivia and Paraguay in the Chaco region. The Commission of Neutrals, consisting of representatives from the United States, Colombia, Uruguay, Cuba and Mexico, tried to promote conciliation and suggested the Declaration of American Republics which was adopted by the nineteen American countries. It stipulated: "The American nations further declare that they will not recognize any territorial arrangement of this controversy which has not been obtained by peaceful means nor the validity of territorial acquisitions which may be obtained through occupation or conquest by force of arms." Dep't State Press Releases, at 100-101 (Aug. 6, 1932).

The declaration apparently produced no results, for in the subsequent settlement of the Chaco conflict non-recognition was never mentioned. Early in 1935 Argentina and Chile proposed a settlement of the conflict. On June 12 the belligerents agreed to the 
conquests of territory in Europe and Asia the United States has stood alone in its refusal to grant recognition. The American experience has shown that non-recognition, when adopted by one nation acting alone, generally has little or no sanctionary effect.

Although, unlike the Stimson note, it did not involve non-recognition of aggression, ${ }^{37}$ the United States' policy which denied recognition to LatinAmerican governments created by revolutionary or unconstitutional means deserves special attention. For, although the effects of non-recognition and of the economic and military pressures ${ }^{38}$ which so often accompanied it are diffcult to separate, significant political changes resulted in some of the LatinAmerican countries whose governments the United States refused to recognize.

In 1903 General Morales seized control of the Dominican Republic. He was told by the United States that his government would be recognized only if it would honor all engagements entered into between the American Legation and the Dominican Republic. The agreements referred to included an arrangement made in 1900 whereby American control would be exercised over the collection of Dominican customs to meet payments on Dominican bonds. Morales agreed and was recognized on January 20,1904. The presence of a United States naval vessel in Dominican waters undoubtedly contributed to the prompt acceptance of our terms, but the threat of non-recognition cannot be ignored..$^{39}$

Although constitutionally elected in December 1920, the Obregón regime of Mexico was refused recognition by the United States until it accepted a proposed treaty which would guarantee restoration and protection of confiscated American interests in Mexico. ${ }^{40}$ Obregón refused, saying his government was unwilling to pay this price for recognition. Mexico's government was unrecognized for two and one-half years. Ultimately a joint Mexican-United States Commission worked out a compromise agreement acceptable to both governments. Simultaneous statements were released to the press in Washington and in Mexico City on August 31, 1923, announcing the renewal of diplomatic relations between the two governments.

Chaco Peace Conference which met in Buenos Aires that summer. A peace treaty was signed on July 21, 1938. For details see Woolsey, The Chaco Dispute, 26 Am. J. Int. L. 796 (1932); Hill, Recent Policies of Non-recognition, International Conciliation no. 293, 398 (Oct. 1933), and references cited therein; Langer, Seizure of Territory 68 (1947).

${ }^{\pi}$ See note 2 supra.

${ }^{38}$ The combination of non-recognition and military intervention is strikingly illustrated by Mexico in 1913, the Dominican Republic from 1913 to 1924 and Honduras from 1923 to 1925.

${ }^{3}$ For more details see the diplomatic correspondence in U.S. Foreign Rel. 261-93 (1904).

${ }^{\circ}$ U.S. Foreign Rel. II, 407 (1921). 
Again non-recognition was not the only factor involved. Large American financial interests and the strong military position of the United States, together with an approach to threats of war, figured substantially in the final resolution of the dispute.

One month after the United States had withdrawn the Marines from Nicaragua in 1925, General Chamorro engineered a coup d'état. The United States denied recognition. Our non-recognition added moral stimulus to a revolution, materially aided by Mexico, which forced Chamorro to turn the government over to Diaz. The Diaz regime was promptly recognized. ${ }^{41}$

In 1930 non-recognition apparently forced the resignation of General Orellana who had seized the presidency of Guatemala through revolution. He assumed office on December 17 , but his government was immediately refused recognition. Orellana resigned and, following the acceptance of former President Chacon's resignation by Congress on January 2, 1931, Reina Andiade was elected Vice-President and elevated to the post of Provisional President. The following February General Ubico was elected President, and his regime was granted recognition by the United States. ${ }^{42}$ Non-recognition seems to have been decisive in determining the outcome of the Guatemalan situation.

Aside from the Guatemalan example, it is difficult to conclude that nonrecognition alone had any significant effect in Latin America, although it may have contributed to the attainment of desired results. ${ }^{43}$ Recurrent criticism of the United States' policy, however, indicates that non-recognition was thought by some to be a successful sanction. At the Inter-American Conference on Problems of War and Peace in Mexico in 1945, a resolution was offered to put an end to the arbitrary use of the recognition instrument. ${ }^{44}$ There have been many criticisms of the Wilson policy as a device of interven-

"Although the constitutionality of the Diaz regime was questionable, we were forced to extend recognition to prevent the further intervention of Mexico.

"The communications between Secretary of State Stimson and the United States Minister in Guatemala, Whitehouse, are interesting in reference to the effect of nonrecognition in ousting Orellana. U.S. Foreign Rel. III, 172-97 (1930). There was apparently no armed intervention; Stimson even refused to dispatch a warship to San Jose to prevent any potential disorders. It appears that the situation was uncertain, that Orellana was in a precarious position, that the impact of American non-recognition together with the non-recognition of other Latin-American countries might have been a decisive factor in removing Orellana. We insisted that he could not be a candidate in the new elections. He did, however, deny personal ambition.

The population of Guatemala at that time was 2,454,000.

${ }^{3}$ No study was found of the effectiveness of our non-recognition policy in Latin America. There are several works which deal indirectly with the topic: Dennis, Revolution, Recognition and Intervention, 9 Foreign Affairs 204 (1931); MacCorkle, American Policy of Recognition towards Mexico (1933); Neumann, Recognition of Governments in the Americas (1947).

" Inter-American Conference on Problems of War and Peace (Washington, 1945), ResoIution XXIV, "Abolition of the Recognition of De Facto Governments," quoted in Neumann, Recognition of Governments in the Americas 47 (1947). 
tion. Such adverse comments seem to assume the effectiveness of the device. ${ }^{45}$ Secretary Stimson was impressed by the policy, and perhaps was encouraged by his view of the Latin-American experience to apply non-recognition to the conquest of Manchuria. ${ }^{46}$

It has been painfully apparent, however, that non-recognition by the United States of governments outside Latin America has had no sanctionary effect. The delayed recognition of Russia gained us nothing. ${ }^{47}$ Non-recogni-

${ }^{\text {¿s }}$ See the criticisms in Dennis, Revolution, Recognition and Intervention, 9 Foreign Affairs 204 (1931), and Neumann, Recognition of Governments in the Americas (1947). For a comment on the Dennis article, see Anderson, Our Policy of Non-recognition in Central America, 25 Am. J. Int. L. 298 (1931). Stimson praised the policy (n. 46 infra). The controversy is over whether our non-recognition policy helped stop revolutions in Latin America or whether it merely intervened in the internal affairs of other nations to the detriment of all parties concerned.

In his Introduction, Neumann, op. cit. supra, states: "By indirect methods a powerful foreign government can use its political and economic strength to force a course of action upon another government as effectively as if it had landed troops upon that government's soil. One of these methods . . . is the use of the recognition instrument. By refusing to recognize a new government in an economically weak country, foreign credits can be checked and foreign trade hindered so that the new regime is financially weakened. The failure of foreign governments to recognize is also a blow to the regime's prestige, and it may encourage oppositionist groups in their efforts to unseat the new government. . . [N]on-recognition ... therefore constitutes intervention."

${ }^{46}$ In an address before the Council on Foreign Reations, New York City, on February 6, 1931, Secretary Stimson said: "Since the adoption by Secretary Hughes, in 1923, of the policy of recognition agreed upon by the five republics in their convention, not one single revolutionary government has been able to maintain itself in those five republics. Twice, once in Nicaragua and once in the case of Guatemala, ... a revolutionary leader has succeeded in grasping the reins of government for a brief period. But in each case the failure to obtain recognition has resulted in his prompt resignation, on account of his inability to borrow money in the international markets. Several times within the same period a contemplated revolution has been abandoned by its conspirators on the simple reminder by a minister from this country or one of the other republics that, even if they were successful, their government would not be recognized; and undoubtedly in many cases has the knowledge of the existence of the policy prevented even the preparation for a revolution or coup d'état. . . . When one compares this record with the bloodstained history of Central America before the adoption of the treaty of 1923, I think that no impartial student can avoid the conclusion that the treaty and the policy which it has established in that locality has been productive of very great good." Quoted in Anderson, Our Policy of Non-recognition in Central America, 25 Am. J. Int. L. 298, 299 (1931).

The Latin-American experience might explain why Secretary Stimson wanted to couple the non-recognition of Manchukuo with more forceful measures, such as an economic boycott. President Hoover, however, was opposed to such a notion, as was Under-Secretary of State Castle, The difference of opinion is brought out in Current, Secretary Stimson: A Study in Statecraft, c. 5 (1954).

"One of the principal reasons for the refusal of the United States to recognize the Soviet government of Russia after 1917 was the unwillingness of the new government to fulfill what the United States regarded as its international obligations in the matter of certain treaties and financial commitments of the Czarist government, of compensation for expropriation of American property, and of revolutionary propaganda abroad. Negotiations between the two governments in 1933 resulted in a compromise settlement and eventual de jure recognition on November 16.

In 1918 and in the following years a considerable number of states refused to recognize 
tion proved similarly unsuccessful as a sanction when applied to the Italian conquest of Ethiopia and Albania, the German conquest of Austria and Czechoslovakia, and the Soviet conquests. Even if non-recognition was effective in Latin America, conditions in Europe and Asia were not sufficiently similar to produce the same results.

\section{III}

Its failure as a sanction has brought about a reconsideration of non-recognition. It is now generally agreed that non-recognition as a manifestation of public opinion can never be an effective sanction. ${ }^{48}$ Some writers even consider non-recognition totally ineffective, if not harmful.49 Others, however, have maintained that non-recognition when applied by many nations can have

the Soviet government for reasons similar to those of the United States. Yet the government of Soviet Russia was subsequently recognized by most of those states without being obliged to give assurances not given reciprocally by the recognizing states. For a detailed account, see Toynbee, Survey of International Affairs, 1924, 228 et seq. (1926); 1 Hackworth, Digest of International Law 289-305 (1940).

${ }^{43}$ Langer, The Seizure of Territory 287 (1947) ; Lauterpacht, Recognition in International Law, c. 21 (1947); Chen, The International Law of Recognition, c. 32 (1951).

${ }^{19} \mathrm{Mr}$. Moore, a former judge of the Permanent Court of International Justice, has criticized it in the following scathing terms: "Its chief weakness lies in the fact that those who employ it often must content themselves with futile words or must fight, while the adoption of the latter alternative would necessarily be a confession of failure. All systems of law recognize, by the doctrine of prescription and otherwise, that the recognition of accomplished facts plays, as a principle of certainty and peace, a large part in human affairs; and nations are but aggregations of human beings, who may not relish daily reminders of their shortcomings by others whom they may not deem above reproach, or wholly disinterested or unprejudiced." Moore, Fifty Years of International Law, 50 Harv. L. Rev. 395, 436 (1937). For comment on this criticism see Williams, 44 Hague Recueil 281 (1933) and The New Doctrine of Recognition, 18 Transactions of the Grotius Society 109, 120-23 (1933); Wild, Sanctions and Treaty Enforcement 160-79 (1934); Borchard and Morrison in Legal Problems in the Far Eastern Conflict 157-58 (Wright ed., 1941).

It may also be argued that non-recognition is a nuisance to the non-recognizing power as well as to the non-recognized government. See Dennis, Revolution, Recognition and Intervention, 9 Foreign Affairs 204 (1931), and Neumann, Recognition of Governments in the Americas (1947).

Other critics have suggested that non-recognition of conquests would tend to "freeze" the status quo. Langer, The Seizure of Territory 118 (1947), suggests, however, that "non-recognition .... cannot be held to outlast a change of the previous territorial status effected by means of a general arrangement in the wake of one of the major international crises which are bound to recur from time to time as long as the international system is based on the principle of the sovereign equality of a number of independent states. . . Unsatisfactory as this result may be, it is still preferable to a system which accepts unilateral acts of aggression as faits accomplis."

It might finally be argued that non-recognition may contribute to the occurrence of a war which it was meant to avoid.

The critics of non-recognition seem to believe that a nation should recognize all governments meeting minimum de facto requirements. 
beneficial effects. ${ }^{50}$ Perhaps one of the most significant of these might be, as Secretary Stimson predicted, a change in international law. ${ }^{51}$

International law has many sources. It originated with the emergence of the nation states at the end of the medieval period when the states found that they needed rules to govern their dealings with one another. The law was compiled by writers drawing from religion, private law, natural law and history. Much of the law of nations is still composed of this rather speculative material. There are some rules of international law, however, which are apparently well established. Writers commonly say, for example, that pacta sunt servanda is a genuine law of nations.

One of the primary sources of international law is the practice of states. If a vast majority of the nation states spontaneously follow a certain course of conduct in a given situation or agree that certain consequences should follow from a particular act, international law results. ${ }^{52}$ It is generally agreed that traditional international law allows the conqueror to obtain title to territory through conquest. ${ }^{53}$ But a general refusal to acknowledge the legality of a

so "Politically, the non-recognition of a forcible seizure of territory is of considerable value for upholding the morale of the population of the seized area, for strengthening their spirit of resistance, not only for their own benefit, but often also for the ultimate benefit of the non-recognizing State, as many recent instances have shown.

"Juridically, non-recognition acts during the occupation on behalf of the nationals of the seized State who find themselves within the jurisdiction of the non-recognizing State, in particular in case war breaks out between the latter and the occupant. After the end of the occupation, non-recognition affords the returning sovereign a clearer legal position regarding the rescission of measures of the dispossessing Power. The questions that arose during and at the end of the Second World War with respect to the personal status and the assets of nationals of occupied countries clearly show the great importance of the Stimson Doctrine in the administrative and judicial fields.

"Ethically, non-recognition is the most pertinent manifestation of the postulate that a unilateral tour de force should not be allowed to bring about a valid change in the existing territorial order." Langer, Seizure of Territory 288 (1947).

Non-recognition of Manchukuo encouraged China to attempt to reconquer it when practicable.

See note 22 supra.

52 Although there is no authority to enforce the rules of international relations, those rules are, nevertheless, law. The existence of an enforcing power is not essential to law.

For discussion on the nature of international law see 1 Austin, Lectures on Jurisprudence 173 (5th ed., Campbell, 1885); Kelsen, General Theory of Law and State (1945) and Law and Peace in International Relations (1942); Morgenthau, Politics among Nations (1948).

* Evans, Leading Cases on International Law 296 (1917); Williams, Sovereignty, Seisin and the League, 7 Brit. Y. B. Int. L. 24, esp, 35, 37, 40, 42 (1926); Lauterpacht, Private Law Sources and Analogies of International Law 105-7 (1927); Eagleton, International Government 91-93 (1932) ; Hill, Claims to Territory in International Law and Relations 161 (1945).

McMahon, Conquest and Modern International Law (1940), gives an excellent historical survey of the international law of conquest. While the majority of the authorities maintain that conquest does and always has given title to territory, there is some dissent. The Natural Law school has steadfastly adhered to the notions of Aquinas and Augustine 
territorial transfer by aggression would effectively change international law: A universal affirmation of non-recognition would make the occupation of all conquered territory illegal.

It is no objection to say that such a change is useless because the law could not be effectively enforced. A distinction must be made between the desirable and the undesirable before force can be applied. In the absence of force, law is, nevertheless, real. It conditions and anticipates.

But non-recognition of conquests is followed by only one nation today. ${ }^{54}$

that conquest is wrong and cannot create a valid claim to land.

An interesting development arose with regard to the Pact of Paris, the Nine Power Treaty and Article 10 of the League of Nations' Covenant. The result of the three treaties made the act of conquest illegal with respect to the signatories. The question remained, granted the act of aggression-i.e., the use of non-pacific means to gain territory-is illegal, whether that illegality necessarily voids any title the conqueror might claim to the territory under the traditional international law of conquest. Lauterpacht seems to take such a position: "In so far as these instruments [the covenant and the Pact] prohibit war, they probably render invalid conquest on the part of the State which has resorted to war contrary to its obligations. An unlawful act cannot normally produce results beneficial to the law-breaker. . . Oppenheim, International Law 453-54 (5th ed., Lauterpacht, 1935) (emphasis supplied).

Lauterpacht argues primarily from private-law analogy. But international law in many ways is, and must be, different from private law. But even in private law there are instances in which an illegal act gives title, e.g., one receives title to the proceeds of illegal acts such as gambling, peddling dope and establishing a monopoly. It seems difficult to push the treaties as far as he does. It would seem better to view the treaties as condemning the means of aggression as illegal but as silent concerning the status of territory once an illegal conquest has been accomplished. The nations have recognized that they do not have the privilege to conquer and have imposed upon themselves the duty not to conquer, but they have said nothing about the results of a wrongful conquest. In the absence of a specific statement, then, the traditional international law of conquest is still operative. That is, conquest, though illegal, gives valid title to territory.

Japan suggested a similar view in its reply to Secretary Stimson on January 16, 1932: "[The Government of Japan] takes note of the statement by the Government of the United States that the latter cannot admit the legality of matters which might impair the treaty rights of the United States or its citizens or which might be brought about by means contrary to the treaty of 27 August 1928. It might be the subject, of an academic doubt, whether in a given case the impropriety of means necessarily and always avoids the ends secured; but as Japan has no intention of adopting improper means, that question does not practically arise." Dep't State Press Releases, at 68 (Jan. 16, 1932). But the question was "academic" since Japan claimed self-defense. See Japan's note of February 23, 1932, to the League Council, L. Nations Off. J. 384 (1932).

Although the three treaties did not declare the "fruits of aggression" illegal, some writers have argued that the Nine Power Treaty, the Pact of Paris and Article 10 of the League of Nation's Covenant imposed an implied duty of non-recognition of conquests upon the signatory nations. If this is true, would not the treaties operate indirectly to change international law, since nearly every nation of the world was a signatory of at least one of the three treaties? Perhaps the universal non-recognition of Manchukuo changed international law. If so, the subsequent refusal to withhold recognition from conquests returned the law to its original position. For further discussion see the authorities cited in note 2 supra.

\footnotetext{
${ }^{56}$ Non-recognition is not implied in the United Nations' Charter. See Langer, The Seizure of Territory $86-92$ (1947).
} 
The non-recognition of one government by another acting alone is neither a sanction nor can it affect the law of nations; nevertheless, it can have value in the international order. It is a manifestation of the proposition that force should not be allowed to cause valid territorial rearrangements. It envisages a world community in which the standard of conduct condemns force and coercion and stealing and which no longer remains passively disconcerted while nations are subjugated.

The reconsideration of the purpose and value of non-recognition is reflected in a reconsideration of the conduct appropriate to a nation invoking nonrecognition. When disapproval through non-recognition is thought to have some impact upon the non-recognized nation, it appears necessary to refrain from that conduct which would imply recognition. Viewing non-recognition in a sanctionary context, the League members and the Advisory Committee felt it essential to impose rigid prescriptions of conduct in order that the disapproval of the world might be adequately manifested. But it has been shown that opinion reflected through non-recognition, whether of one or more nations, has not in itself proved an effective sanction. The value of non-recognition, if any exists, is not to alter policies of the non-recognized government, but to effect some other purpose, such as to change international law. Whether the non-recognizing government refrains from acts traditionally thought forbidden by non-recognition is of no consequence to the achievement of such a purpose.

Yet if a government is committed to a policy of non-recognition, there is a "duty" not to engage in any conduct that would imply recognition of that which should not be recognized. It has been seen that recognition may be either express or implied; the essential element is the intention of the recognizing government. In the absence of an express declaration to the contrary, certain conduct, e.g., the conclusion of a treaty, is sufficient to imply an intention to recognize. In the presence of an express statement of an intention not to recognize, however, such conduct cannot imply recognition. The possibility of implied recognition is abolished by an express declaration of non-recognition. ${ }^{55}$

\footnotetext{
${ }^{5}$ Lauterpacht distinguishes between a contemporaneous statement and a standing policy of non-recognition. He says: "Any general attitude of non-recognition, i.e., the proclaimed assumption of the policy or obligation of non-recognition, has a direct bearing on the operation of the doctrine of implied recognition. It reduces the operation of that doctrine even below the modes and limits which can otherwise be assigned to it. This means that particularly exacting evidence of recognition is required in the case of states which have declared themselves to be pursuing a policy of non-recognition or, even more so, as being bound by an obligation of non-recognition." But he does admit that "[t]here is room for the view that in such circumstances nothing short of an explicit and unequivocal act of recognition will have the result of recognition. Whatever other effects the doctrine of non-recognition may have, this much may be expected of it, that it has at least the effect of ruling out implied recognition. In the circumstances, any caveat which might otherwise be necessary is redundant." Lauterpacht, Recognition in International Law 395-96 (1947).
} 
Hence, it violates neither the purpose nor the legal concept of non-recognition for a non-recognizing government to engage in that conduct which might ordinarily imply recognition, if an express statement of non-recognition has been issued.

It follows that the conduct of the United States mentioned at the beginning of this comment does not show that the United States has ceased to pursue a policy of non-recognition. ${ }^{56}$ On the contrary, it has done so consistently. In determining whether it should continue to do so, the limited potentialities of non-recognition must be taken into account. The United States may decide to continue to deny recognition to conquering nations-by declarations of refusal to recognize-in the hope that as a result aggression may one day be outlawed by the international community. With the limitations of non-recognition in mind, it can deny recognition and yet be free to prosecute its foreign policy unhampered by the inhibitions which a sanctionary view of non-recognition entails.

${ }^{E 8}$ The three instances of questionable conduct mentioned above are not inconsistent with non-recognition.

(a) The non-recognition policy of the United States toward conquests was well known in 1939; hence, the extradition treaty with Germany could not have implied recognition of the conquest of Austria, although the United States did not issue an express statement of non-recognition until later. Some difficulty could have been avoided had the declaration been made earlier. The case of United States ex rel. Zdunic v. Uhl, 46 F. Supp. 688 (1942), rehearing denied 47 F. Supp. 520 (1942), rev'd and remanded 137 F. 2d 858 (C.A. 2d, 1943), rehearing 56 F. Supp. 403 (1943), aff'd, rehearing denied 144 F. 2d 286 (C.A. 2d, 1944), illustrates the confusion arising from the court's efforts to ascertain whether we had implied recognition of Germany's conquest of Austria.

(b) In view of our non-recognition policy our dealings with the Soviet Union could not imply recognition of their legal control of Latvia. Yet the United States could have argued in the dispute that it did not recognize that the Soviets had any right to be in Latvia and, hence, that they had no right to order our plane to land or to shoot at our plane in an effort to protect Latvia. Our failure to make that defense did not destroy our non-recognition, but perhaps it indicated the practical significance the State Department attached to the non-recognition policy.

(c) The announcement that our meeting with the Chinese Communist government was not to imply recognition vitiated any possibility of recognition.

\section{PERMISSIBLE EMPLOYEE DISLOYALTY AND THE DUANE JONES CASE}

An employee's loyalty to his firm during the term of his employment is expected as a matter of course. Often, however, an employee desires to change positions or to enter business for himself, and while still employed he may be making detailed plans toward that end.

Caught between the desirability of free competition and the protection of a vested interest, the law has taken a middle ground. At no time may the 